\title{
PENGARUH PENGGUNAAN METODE DRILL TERHADAP HASIL BELAJAR AKUNTANSI KELAS X SEMESTER GENAP SMK NEGERI 1 METRO TAHUN PELAJARAN 2015/2016
}

\author{
Noviyana Sari ${ }^{1)}$ Maryatun ${ }^{2)}$ \\ Pendidikan Ekonomi FKIP Universitas Muhammadiyah Metro \\ Noviyana.Arifin@gmail.com\&com\&maryatun@yahoo.com
}

\begin{abstract}
Abstrak
Penelitian ini bertujuan untuk mengetahui pengaruh penggunaan Metode DRill terhadap hasil belajar Akuntansi. Metode penelitian yang digunakan adalah quasi eksperimental design berbentuk noneqiuvalent control group design. Dari analisis data menunjukkan hasil belajar Akuntansi mengalami peningkatan $40 \%$ dilihat dari perbandingan evaluasi pretest dan evaluasi posttest, yaitu peserta didik yang mencapai kriteria ketuntasan minimal pada evaluasi pretest adalah 30\%, sedangkan peserta didik yang mencapai kriteria ketuntasan minimal pada evaluasi posttest adalah $70 \%$. Berdasarkan hasil penelitian tersebut maka hipotesis dapat diterima sebab $t_{\text {hitung }}\left(t_{\text {hit }}\right)=13.08$ lebih besar daripada $t_{\text {tabel }}\left(t_{\text {tab }}\right)=1.70$ dan 2.47. Dengan demikian menunjukkan bahwa "ada pengaruh yang positif penggunaan Metode Drill terhadap hasil belajar Akuntansi kelas X semester genap SMK Negeri 1 Metro tahun pelajaran 2015/2016."
\end{abstract}

\section{Kata Kunci : Metode Drill, Hasil Belajar Akuntansi}

\section{PENDAHULUAN}

Pendidikan merupakan salah satu sektor penting dalam pembangunan disetiap negara. Berhasil tidaknya pendidikan yang dilaksanakan akan menentukan maju mundurnya negara tersebut. Dunia pendidikan tidak terlepas dari belajar dan hasil belajar. Belajar adalah mengamati, membaca, meniru, mencoba sesuatu, mendengar dan mengikuti arah tertentu. Pendapat di atas dapat disimpulkan bahwa belajar adalah suatu proses yang dilakukan seseorang dengan mengamati, membaca, meniru, mencoba sesuatu, mendengar dan mengikuti arah tertentu, serta dari yang tidak bisa menjadi bisa, dari yang tidak tahu menjadi tahu. Rendahnya hasil belajar Akuntansi disebabkan karna banyaknya masalah yang mempengaruhi. Dari hasil observasi dan wawancara dengan guru bidang studi Akuntansi bahwa rendahnya hasil belajar disebabkan karna masih banyaknya peserta didik yang bermain-main saat pembelajaran dimulai atau masih banyak peserta didik yang melakukan aktivitas lain pada saat pembelajaran berlangsung. Melihat permasalahan di atas maka metode drill dipandang relevan dengan masalah di atas dalam rangka untuk meminimalisir perrmasalahan tersebut. Karna metode drill dapat mengembangkan ke cakapan intelek seperti menghitung, mengalikan menjumlah dan ilmu-ilmu pasti lainya. Sehingga sesuai dengan mata pembelajaran Akuntansi. 
Adapun tujuan dalam penelitian ini adalah untuk mengetahui pengaruh penggunaan Metode Drill terhadap hasil belajar Akuntansi kelas X semester genap SMK Negeri 1 Metro Tahun pelajaran 2015/2016. Metode Drill adalah suatu pembelajaran dimana peserta didik melaksanakan kegiatan-kegiatan latihan, agar peserta didik memiliki ketangkasan atau ketrampilan yang lebih tinggi dari apa yang telah dipelajar.

\section{KAJIAN PUSTAKA}

\section{Pengertian Metode Drill}

Menurut Sujana (2011:87) "Metode Drill digunakan pada umunya untuk memperoleh suatu ketangkasan atau keterampilan dari apa yang telah dipelajari. Dan untuk memperoleh kecakapan motorik".

Dalam menggunakan metode ini guru hendaknya memperhatikan hal-hal yang harus diperhatikan dalam metode ini.

a. Latihan wajar digunakan untuk hal-hal yang bersifat motorik, seperti menulis, permainan, pembuatan dan berhitung.

b. Mengembangkan kecakapan intelek, seperti mengalikan, menjumlah. Mengenal benda/bentuk dalam pembelajaran matematika,atau ilmu perhitungan yang lain, ilmu pasti, ilmu kimia, dan sebagainya.

c. Untuk melatih kecakapan mental perhitungan, penggunaan rumusrumus dan lain-lain.

d. Untuk melatih hubungan, tanggapan seperti penggunan bahasa, simbul dan peta.

Menurut Roestiyah

"Metode Drill adalah suatu pembelajaran dimana peserta didik melaksanakan kegiatan-kegiatan latihan, agar peserta didik memiliki ketangkasan atau ketrampilan yang lebih tinggi dari apa yang telah dipelajari”.

Selain itu menurut Bahri (2010:88)

"Metode Drill adalah suatu cara pembelajaran yang baik untuk menanamkan kebiasaan-kebiasaan tertentu. Juga sebagai sarana untuk memelihara kebiasaan baik".Selain itu metode ini dapat juga digunakan untuk memperoleh suatu ketangkasan, dan ketrampilan.

Berdasarkan pendapat para ahli dapat diambil kesimpulan bahwa metode drill adalah suatu cara pembelajaran dimana peserta didik mendapat kecakapan dan ketrampilan yang lebih tinggi dari sebelumnya dan mudah mengerti dari apa yang telah dipelajari sehingga siswa memperoleh suatu ketrampilan dan kecakapan secara sempurna.

$$
\text { Menurut Roestiyah }
$$
menjelaskan langkah-langkah metode drill adalah sebagai berikut :

1. Gunakan latihan ini hanya untuk mata pembelajaran yang dilakukansecara otomatis, tanpa menggunakan pemikiran yang dan pertimbangan yang mendalam. Tetapi dapat dilakukan dengan cepat seperti gerak reflekss. Misal, menghafal, menghitung,dan sebagainya.

2. Guru harus memilih latihan yang mempunyai arti luas yang dapat menanamkan pengertian pemahaman akan makna dan tujuan latihan sebelum mereka melakukan. Sehingga latihan mampu menyandarkan siswa akan kegunaan bagi kehidupannya saat sekarang ataupun masa yang akan mendatang.

3. Guru harus menekankan diagnosa, karena latihan permulaan belum bisa mengaharapkan siswa mendapatkan keterampilan yang sempurna. Pada latihan berikutnya guru meneliti 
hambatan yang timbul dan dialami peserta didik, sehingga dapat memilih atau menentukan latihan mana yang perlu diperbaiki.

4. Perlu mengutamakan ketepatan, dan memperhatikan kecepatan agar peserta didik melakukan kecepatan dan ketrampilan menurut waktu yang telah di tentukan.

5. Guru memperhatikan waktu ketika latihan agar tidak terlalu lama dan tidak terlalu singkat, karna jika terlalu lama akan membosankan. Masa latihan itu harus menyenangkan dan menarik sehingga menimbulkan optimisme dan rasa gembira yang bisa menghasilkan ketrampilan yang baik.

6. Guru dan siswa mengutamakan proses-proses yang esensial/yang pokok dan tidak terlibat pada hal-hal yang tidak diperlukan.

7. Guru perlu memperhatikan perbedaan individual siswa, sehingga kemampuan dan kebutuhan masingmasing siswa dapat berkembang.

8. Guru dan peserta didik menyimpulkan dari hasil latihan.

Berdasarkan pendapat ahli di atas dapat disimpulkan bahwa latihan ini untuk mata pembelajaran yang dilakukan secara otomatis, tanpa menggunakan pemikiran dan pertimbangan yang mendalam dan mempunyai arti luas yang dapat menanamkan pengertian pemahaman akan makna dari latihan yang didapat. Berdasarkan pendapat diatas penulis menentukan indikatornya yaitu: a) memilih latihan, b) menjelaskan tujuan latihan, c) menentukan alokasi waktu, d) diskusi dan evaluasi, e) kesimpulan.

Sebagai suatu metode yang diakui banyak mempunyai kelebihan, juga tidak dapat dipungkiri bahwa metode drill juga mempunyai beberapa kelemahan. Menurut
Bahri (2010:96) Menyatakan bahwa adapun kelebihan dan kelemahan dari metode ini adalah sebagai berikut:

a) Kelebihan MetodeDrill

1. Untuk mencari kecerdasan atau kecakapan motoric, seperti menulis, melafalkan huruf, katakata, menggunakan alat-alat (mesin permainan dan atlentik)

2. Untuk memperoleh kecakapan mental seperti dalam perkalian, menjumlahkan, pembagian tandatanda atau simbol-simbol dan sebagainya.

3. Untuk memperoleh kecakapan dalam bentuk asosiasi, yang dibuat seperti hubungan huruf-huruf dalam ejaan, penggunakan simbul, membaca peta dan sebagainya.

4. Pembentukan kebiasaan yang dilakukan dan menambah ketetapan serta kecepatan pelaksanaan.

5. Pembentukan kebiasaan-kebiasaan membuat gerakan-gerakan yang kompleks, rumit, menjadi lebih otomatis.

b) Kelemahan Metode Drill

1. Menghambat bakat dan inisiatif peserta didik, karna peserta didik lebih banyak dibawa kepada penyesuaian dan diarahkan jauh dari pengertian.

2. Menimbulkan penyesuaian secara statis kepada lingkungan.

3. Kadang-kadang latihan yang dilaksanakan secara berulang-ulang merupakan hal yang monoton.

4. Dapat menimbulkan verbalisme.

\section{Pengertian Hasil Belajar}

Hasil belajar merupakan interaksi atau hubungan timbal balik antara peserta didik dengan pendidik dan antara peserta didik dengan peserta didik dalam proses pembelajaran. Istilah belajar berarti 
mempelajari suatu materi dari yang tidak tahu menjadi tahu, dan dari yang tidak bisa menjadi bisa. Keberhasilan pelajaran Akuntansi ditentukan oleh seberapa baik hasil belajar yang dicapai peserta didik setelah mengikuti proses pembelajaran.

Menurut Gagne (dalam Uno, 2008:137) Menyatakan bahwa "Hasil belajar merupakan kapasitas terukur dari perubahan individu yang diinginkan berdasarkan ciri-ciri atau variabel bawaannya melalui perlakuan pembelajaran tertentu". Menurut Abdurahman (2003:37) menyatakan bahwa "Hasil belajar adalah kemampuan yang diperolah anak setelah melalui kegiatan belajar. Belajar itu sendiri merupakan suatu proses dari seseorang yang berusaha untuk memperoleh suatu bentuk perubahan perilaku yang relatif menetap.

Menurut Uno (2008:213) menyatakan bahwa "Hasil belajar adalah perubahan prilaku yang relatif menetap dalam diri seseorang sebagai akibat dari interaksi seseorang dengan lingkunganya".

Menurut Kunandar

$(2007: 251)$

menyatakan bahwa:

Hasil belajar adalah kemampuan peserta didik dalam memenuhi suatu tahapan pencapaian pengalaman belajar dalam satu kompetensi dasar. Hasil belajar dalam silabus berfungsi sebagai tanda-tanda yang menunjukkan terjadinya perubahan perilaku yang akan dicapai oleh peserta didik sehubungan dengan kegiatan belajar yang dilakukan, sesuai dengan kompetensi dasar dan materi standar yang dikaji. Hasil belajar bisa berbentuk pengetahuan, ketrampilan, maupun sikap.
Berdasarkan pendapat para ahli dapat disimpulkan bahwa hasil belajar adalah kemampuan individu yang di tandai dengan ketercapaian belajarnya dalam satu kompetensi dasar. Dimana kompetensi dasar merupakan kemampuan minimal pada siwa yang ditentukan dari tiap mata pembelajaran yang harus dicapai peserta didik. Sedangkan hasil belajar silabus merupakan perubahan perilaku individu berdasarkan ketercapaian individu yang diukur dari kompetensi-kompetensi dasar yang didapat drai pengalam individuindividu, perubahan perilaku ini dapat berupa pengetahuan, ketrampilan, maupun sikap yang dimiliki setiuap individu.

\section{METODOLOGI PENELITIAN}

Penelitian ini merupakan penelitian yang bersifat pengaruh, yang mengkaji pengaruh antara variabel bebas dan variabel terikat. Penelitian ini mencari bagaimana pengaruh penggunaan metode Drill terhadap hasil belajar Akuntansi. Dalam penelitian ini, desain penelitian true Eksperimen Design demean bentuk Pretest-posttest Control Grup Design dan penulis menggunakan teknik sampling purposive dimana dalam penentuan sampel dengan menggunakan pertimbangan tertentu.

Populasi dalam penelitian ini sebanyak 2 kelas dan dengan jumlah 62 peserta didik maka peneliti memperoleh sampel bahwa kelas X P2 yang berjumlah 31 peserta didik sebagai sampel (kelas eksperimen) dalam penelitian serta kelas $\mathrm{X}$ P3 yang berjumlah 31 peserta didik sebagai kontrol (kelas kontrol).

Dengan terpilihnya kelas $\mathrm{X} \quad \mathrm{P} 2$ sebagai sampel penelitian yang akan 
dijadikan kelas eksperimen. Maka peneliti memiliki suatu pertimbangan, yaitu dari segi proses pembelajaran banyak peserta didik yang kurang aktif/pasif sehingga dalam kelas ini guru yang terlalu aktif dan dari segi hasil belajar kelas X P2, banyak peserta didik yang belum tuntas pada mata pelajaran Akuntansi.

Instrumen yang akan digunakan dalam penelitian ini adalah dengan menggunakan tes. Tes tersebut berisikan soal-soal yang relevan terkait dengan materi yang telah disampaikan dalam kegiatan pembelajaran. Instrumen tes ini terdapat 2 macam yaitu pre tes dan post tes. Masing-masing instrumen ini terdapat 20 soal pilihan ganda yang memiliki 5 pilihan yaitu a, b, c, d, dan e. Dengan adanya instrumen, diharapkan dapat mengukur penguasaan materi dari peserta didik sebelum dan setelah mengikuti kegiatan pembelajaran dari hasil pre tes dan pos tes yang diberikan.

Teknis analisis data dalam penelitian ini meliputi uji normalitas, uji homogenitas dan uji hipotesis. Uji hipotesis menggunakan rumus regresi linier sederhana menurut Sudjana, (2005:315) yaitu $\hat{Y}=a+b X$. Dengan teknik analasis data ini dapat diketahui hipotesis dapat diterima atau ditolak sesuai dengan kriteria uji yang ada.

\section{PEMBAHASAN HASIL PENELITIAN}

Penelitian ini dilaksanakan pada semester genap di SMK Negeri 1 Metro Tahun Pelajaran 2015/2016. Penelitian ini teknik untuk menetapkan sampel dilakukan dengan menggunakan teknik pengambilan sampel teknik sampling purposive. Pengambilan sampel ini dilakukan dengan menggunakan pertimbangan tertentu. Kelas $\mathrm{X}$ yang terdiri dari 12 kelas, kemudian terpilih kelas X pemasaran 2 yang berjumlah 31 siswa sebagai kelas eksperimen dan kelas $\mathrm{X}$ pemasaran 3 sebagai kelas kontrol. Pelaksanaan pengambilan data dimulai tanggal 5 Januari sampai 19 Januari 2016 pada kelas $\mathrm{X}$ pemasran $2(\mathrm{P} 2)$ dan $\mathrm{X}$ pemasaran 3 (P3) semester genap SMK Negeri 1 Metro tahun pelajaran 2015/2016 yaitu data nilai hasil pre-test sebelum kelompok eksperimen diberikan treatment dan data hasil post-test sesudah kelompok eksperimen mendapatkan treatment menggunakan metode Drill dalam proses pembelajaran pada materi pokok tentang memahami pencatatan transaksi.

Hasil perhitungan uji coba instrumen menggunakan rumus KR-20. Adapun hasil reliabilitas pada pretes yaitu sebesar 0,553, maka dapat diperoleh kesimpulan bahwa soal tes pilihan ganda (instrument) tersebut memiliki kriteria cukup. Reliabilitas dalam pretes termasuk pada jika harga $\mathrm{r}$ bila dilihat dalam kriteria reliabilitas diatas, ternyata terletak pada interval 0,4000,599. Sedangkan hasil perhitungan reliabilitas pada posttes yaitu sebesar 0,642, maka dapat diperoleh kesimpulan bahwa soal tes pilihan ganda (instrument) tersebut memiliki kriteria tinggi. Reliabilitas dalam pretes termasuk pada jika harga $r$ bila dilihat dalam kriteria reliabilitas diatas, ternyata terletak pada interval 0,600-0,799.

Dalam penelitian ini data hasil belajar meliputi dua macam yaitu data yang diperoleh dari hasil pretes dan data hasil post tes. Data hasil pretes diberikan pada peserta didik sebelum peserta didik diberi perlakuan menggunakan Metode 
Drill untuk mengetahui keadaan awal hasil belajar Akuntansi. Data hasil post tes diberikan pada peserta didik setelah peserta didik diberikan perlakuan (treatment) menggunakan Metode Drill.

Analisis data tentang hasil belajar Akuntansi pada peserta didik diberi evaluasi pretes ditetapkan dengan data primer yang diambil dari nilai hasil uji pretes. Hasil pretes ini selanjutnya dianalisis untuk memperoleh gambaran atau keadaan awal hasil belajar Akuntansi sebelum diberikan perlakuan atau treatment menggunakan Metode Drill. Dalam hasil prestes diketahui, nilai tes terbesar adalah 70 dan nilai terkecil adalah 45 serta peserta didik yang tuntas dalam hasil pretes terdapat 6 peserta didik. Sedangkan analisis data tentang hasil belajar Akuntansi peserta didik yang diberi perlakuan atau treatment menggunakan Metode Drill, maka ditetapkan dengan data primer yang diambil dari nilai hasil uji post tes. Hasil post tes ini selanjutnya dianalisis untuk memperoleh kesimpulan hasil belajar Akuntansi setelah diberikan perlakuan atau treatment menggunakan Metode Drill . Dalam hasil poststes diketahui, nilai tes terbesar adalah 85 dan nilai terkecil adalah 45 serta peserta didik yang tuntas dalam hasil posttes terdapat 20 peserta didik.

Untuk menganalisis data sebagai objek dari penelitian adalah nilai pretes dan nilai posttes Akuntansi yang diberikan pada peserta didik Sedangkan nilai yang digunakan dalam perhitungan untuk menguji hipotesis adalah nilai yang telah diperoleh dari hasil pengujian.

Hasil dari uji normalitas pada hasil pretest, ternyata untuk taraf nyata Dari perhitungan di atas terlihat bahwa baik untuk taraf nyata $(\alpha)=10 \%$ maupun taraf nyata $(\alpha)=2 \%$ ternyata $F_{\text {hit }}<f_{\text {daf }}$, untuk kreteria $10 \%$ yaitu : $0,96<1,84$ dan untuk taraf nyata $2 \%$ yaitu : $0,96<2,38$. Berdasarkan kriteria uji diatas, maka dapat disimpulkan bahwa $\mathrm{H}_{0}$ diterima. Hal ini menunjukkan bahwa kedua sampel berasal dari populasi yang memiliki varians yang sama atau kedua populasi dalam keadaan homogen. Karena kedua kelompok sampel yang diambil dan diketahui berasal dari populasi yang berdistribusi normal dan homogen, maka dilanjutkan dengan pengujian hipotesis.

Berdasarkan kriteria uji diatas maka dapat disimpulkan bahwa $\mathrm{H}_{0}$ diterima. Hal ini menunjukan bahwa distribusi frekuensi nilai pretes pada peserta didik dari populasi yang berdistribusi normal.

Hasil analisis uji normalitas pada hasil posttes, ternyata untuk taraf nyata Analisis perhitungan nilai $t_{\text {hitung }}$ dan $t_{\text {tabel }}$ tersebut di atas berarti diketahui bahwa $t_{\text {hitung }}>t_{\text {tabel. }}$. Dapat dilihat pada daftar $\mathrm{G}$, pada daftar signifikan $5 \%$ yaitu $3>1,70$, dan pada taraf signifikan $1 \%$ yaitu $3>2,46$.

Berdasarkan kriteria uji diatas, maka dapat disimpulkan bahwa $\mathrm{H}_{0}$ diterima. Hal ini menunjukan bahwa kedua sampel berasal dari populasi yang memiliki varians yang sama atau kedua populasi dalam keadaan homogen. Karena kedua kelompok sampel yang diambil diketahui berasal dari populasi yang berdistribusi normal dan homogen, maka dilanjutkan dengan pengujian hipotesis

Dengan demikian hipotesisnya berbunyi : Ada pengaruh yang positif penggunaan metode drill terhadap hasil belajar akuntansi siswa kelas X SMK Negeri 1 Metro Tahun Pelajarn 2015/2016, maka hipotesisnya diterima. 


\section{PEMBAHASAN HASIL PENELITIAN}

Analisis data tentang hasil belajar Akuntansi pada peserta didik diberi evaluasi pretes ditetapkan dengan data primer yang diambil dari nilai hasil uji pretes. Hasil pretes ini selanjutnya dianalisis untuk memperoleh gambaran atau keadaan awal hasil belajar Akuntansi sebelum diberikan perlakuan atau treatment menggunakan Metode Drill. Dalam hasil prestes diketahui, nilai tes terbesar adalah 70 dan nilai terkecil adalah 45 serta peserta didik yang tuntas dalam hasil pretes terdapat 6 peserta didik.

Sedangkan analisis data tentang hasil belajar Akuntansi peserta didik yang diberi perlakuan atau treatment menggunakan Metode Drill, maka ditetapkan dengan data primer yang diambil dari nilai hasil uji post tes. Hasil post tes ini selanjutnya dianalisis untuk memperoleh kesimpulan hasil belajar Akuntansi setelah diberikan perlakuan atau treatment menggunakan Metode Drill . Dalam hasil poststes diketahui, nilai tes terbesar adalah 85 dan nilai terkecil adalah 45 serta peserta didik yang tuntas dalam hasil posttes terdapat 20 peserta didik.

Untuk menganalisis data sebagai objek dari penelitian adalah nilai pretes dan nilai posttes Akuntansi yang diberikan pada peserta didik Sedangkan nilai yang digunakan dalam perhitungan untuk menguji hipotesis adalah nilai yang telah diperoleh dari hasil pengujian.

Hasil dari uji normalitas pada hasil pretest, ternyata untuk taraf nyata Dari perhitungan di atas terlihat bahwa baik untuk taraf nyata $(\alpha)=10 \%$ maupun taraf nyata $(\alpha)=2 \%$ ternyata $F_{\text {hit }}<\mathrm{f}_{\text {daf }}$, untuk kreteria $10 \%$ yaitu : $0,96<1,84$ dan untuk taraf nyata $2 \%$ yaitu : $0,96<2,38$. Berdasarkan kriteria uji diatas, maka dapat disimpulkan bahwa $\mathrm{H}_{0}$ diterima. Hal ini menunjukkan bahwa kedua sampel berasal dari populasi yang memiliki varians yang sama atau kedua populasi dalam keadaan homogen. Karena kedua kelompok sampel yang diambil dan diketahui berasal dari populasi yang berdistribusi normal dan homogen, maka dilanjutkan dengan pengujian hipotesis.

Berdasarkan kriteria uji diatas maka dapat disimpulkan bahwa $\mathrm{H}_{0}$ diterima. Hal ini menunjukan bahwa distribusi frekuensi nilai pretes pada peserta didik dari populasi yang berdistribusi normal. Hasil analisis uji normalitas pada hasil posttes, ternyata untuk taraf nyata Analisis perhitungan nilai $t_{\text {hitung }}$ dan $t_{\text {tabel }}$ tersebut di atas berarti diketahui bahwa $t_{\text {hitung }}>t_{\text {tabel. }}$. Dapat dilihat pada daftar G, pada daftar signifikan $5 \%$ yaitu $3>1,70$, dan pada taraf signifikan $1 \%$ yaitu $3>2,46$.

Setelah siswa mendapatkan treatment atau perlakuan Metode Drill hasil belajar Akuntansi mengalami peningkatan dilihat dari perbandingan pada evaluasi pretest dan evaluasi posttest, yaitu siswa yang mencapai kriteria ketuntasan minimal pada evaluasi pretest adalah 19,4\% atau 6 siswa dari total keseluruhan siswa 31 siswa, sedangkan siswa yang mencapai kriteria ketuntasan minimal pada evaluasi posttest adalah $64,5 \%$ atau 20 siswa, dari total keseluruhan siswa sebanyak 31 siswa. Secara keseluruhan bahwa setelah siswa mendapatkan treatment, Metode Drill hasil belajar Akuntansi mengalami peningkatan, karena penggunaan Metode Drill ini menekankan siswa lebih aktif dalam proses pembelajaran. 


\section{KESIMPULAN}

Berdasarkan penelitian dan analisis data yang telah dilakukan oleh peneliti, maka dapat diambil kesimpulan bahwa penggunaan Metode Drill berpengaruh positif terhadap hasil belajar Akuntansi khususnya materi pencatatan transaksi pada siswa kelas X SMK Negeri 1 Metro. Kesimpulan tersebut dibuktikan dengan adanya temuan-temuan hasil belajar yang meningkat setelah diberikan perlakuan atau treatment menggunakan Metode Drill dalam proses pembelajaran yang telah dianalisis dan diuji hipotesisnya.

Maka hasil perhitungan regresi linier sederhana dengan rumus $\hat{\mathrm{Y}}=\mathrm{a}+\mathrm{b} \mathrm{X}$ adalah $\hat{Y}=43,0569+0,4864 X$. Dari hasil tersebut kemudian dilakukan pengujian hipotesis dengan rumus $\mathrm{t}_{0}=\frac{b}{S_{b}}$ Setelah diketahui $t_{\text {hitung, maka langkah }}$ selanjutnya adalah membandingkan dengan $t_{\text {tab. }}$. Jika $t_{\text {hitung }}>t_{\text {tab }}$ berarti hipotesis diterima, dan apa bila $t_{\text {hitung }}<\mathrm{t}_{\text {tab }}$ berarti hipotesis ditolak. Dengan analisis penghitungan nilai $t_{\text {hitung }}$ dan $t_{\text {tabel }}$ tersebut, diketahui bahwa $t_{\text {hitung }}>t_{\text {tabel }}$, dan $t_{\text {tabel }}$ dapat dilihat pada daftar $\mathrm{G}$, pada taraf signifikan $5 \%$ yaitu $3>1,70$, dan padataraf signifikan $1 \%$ yaitu $3>2,46$.

Dengan demikian hipotesis yang berbunyi“terdapat pengaruh penggunaan Metode Drill terhadap hasil belajar Akuntansi kelas X semester genap SMK Negeri 1 Metro" maka hipotesis tersebut diterima. Dapat dikatakan diterima karena bisa dilihat dari hasil belajar yang mengalami perubahan kearah yang positif dari 35,5\% atau 11 siswa menjadi 64,5\% atau 20 siswa, dengan kata lain hasil belajar dari proses pembelajaran menggunakan Metode Drill mengalami peningkatan. Jadi Metode Drill dapat digunakan dalam proses pembelajaran untuk meningkatkan hasil belajar, terutama dalam mata pelajaran Akuntansi.

Berdasarkan kesimpulan yang dipapar diatas, maka penulis mencoba mengemukakan saran-saran guna meningkatkan hasil belajar sebagai berikut:

1. Guru diharapkan dapat memilih metode yang tepat dalam proses pembelajaran yang disesuaikan dengan materi akan dipelajari serta disesuaikan dengan sarana dan prasarana yang tersedia, sehingga tujuan dari pembelajaran dapat tercapai. Metode Drill merupakan salah satu metode yang efektif dalam menigkatkan keaktifan siswa dalam kegiatan pembelajaran.

2. Untuk meningkatkan hasil belajar, saya mengharapkan model pembelajaran ini sebagai cara alternatif untuk bisa diterapkan di sekolah, Alternatif model pembelajaran yang penulis sarankan yaitu Metode Drill karena metode ini membut proses pembelajaran tidak menjadi jenuh dan menciptakan suasana belajar yang menyenangkan dalam proses pembelajaran.

3. Diharapkan bagi siswa agar dapat lebih berperan aktif dalam mengikuti proses pembelajaran di kelas serta memahami materi dan bersemangat dalam mengikuti pelajaran yang diberikan oleh guru dengan lebih baik lagi, sehingga dapat meningkatkan hasil belajar terutama pada bidang studi Akuntansi.

Dengan tiga hal tersebut di atas mudah-mudahan dapat bermanfaat dengan 
e-ISSN : 2442-4994 Vol.4. $\mathcal{N} 0.2$ (2016) 69-77

$p$-ISSN : $2337-4721$

baik untuk meningkatkan hasil belajar siswa dalam proses pembelajaran.

\section{DAFTAR PUSTAKA}

Abdurahman,Mulyono.2003.Pendidikan

Bagi Anak Berkesulitan

Belajar.Jakarta: PT Rineka Cipta.

Bahri Djamarah, Syaiful. 2010. Strategi Belajar Mengajar. Jakarta: Rineka Cipta.

Kunandar.2007. Guru Profesional Implementasi Tingkatan Satuan Pendidikan (KTSP) dan Sukses dalam Sertifikasi Guru.Jakarta : Raja Grafindo Persada.

Roestiyah. 2008. Strategi Belajar Mengajar. Jakarta: Rineka Cipta.

Sudjana, Nana. 2011. Dasar-Dasar Proses Belajar Mengajar. Bandung: Sinar Baru Algesindo.

Uno, Hamzah B. 2008. Model Pembelajaran Menciptakan Proses Belajar Mengajar yang Kreatif dan Efektif. Jakarta: Bumi Aksara. 